\title{
The elderly in family health units: morbidity and use of health care services
}

\author{
Idosos na unidade de saúde da família: morbidade e utilização de serviços de saúde \\ Ancianos en unidad de salud familiar: morbilidad y utilización de servicios de salud
}

Renata Cabrelli ${ }^{1}$, Cristina Silva Sousa ${ }^{1}$, Ruth Natalia Teresa Turrini ${ }^{1}$, Tamara Iwanow Cianciarullo ${ }^{1}$

This cross-sectional study aimed to identify the profile of morbidity and use of health services by the elderly in the Family Health Program Antonio Estevão de Carvalho, from São Paulo, Brazil. The information of 92 seniors from the database of the project "Family Health - assessment of the new assistance strategy in the setting of public policies" were used. A descriptive data analysis showed the elderly with an average age of 70.6 years old; $64.1 \%$, females; $93.5 \%$ reported any kind of health problems, especially hypertension (67.4\%) and diabetes mellitus (19.6\%), 77.3\% looked for health care; public hospitals $(42.4 \%)$ were the most sought after services. The reasons for the choice of services were ease of access (18.5\%) and need of care (7.6\%). The main reason of satisfaction was the interpersonal care and of dissatisfaction the lack of medicines and the long wait to set appointments.

Descriptors: Health of the Elderly; Family Health Program; Health Services; Consumer Satisfaction.

Estudo transversal com o objetivo de identificar o perfil de morbidade e de utilização dos serviços de saúde dos idosos atendidos em Programa de Saúde da Família Antonio Estevão de Carvalho, de São Paulo, Brasil. Utilizaram-se as informações de 92 idosos do banco de dados do projeto "Saúde da Família - avaliação da nova estratégia assistencial no cenário das políticas públicas". Análise descritiva dos dados mostrou idosos com idade média de 70,6 anos; $64,1 \%$ do sexo feminino; 93,5\% referiram algum problema de saúde, principalmente hipertensão arterial $(67,4 \%)$ e diabetes mellitus $(19,6 \%)$; $77,3 \%$ procuraram assistência à saúde; hospital público $(42,4 \%)$ foi o serviço mais procurado. Os motivos da escolha dos serviços foram facilidade no acesso (18,5\%) e necessidade de atendimento (7,6\%). 0 principal motivo para a satisfação foi o atendimento interpessoal e para a insatisfação, a falta de medicamentos e a longa espera no agendamento das consultas. Descritores: Saúde do Idoso; Programa Saúde da Família; Serviços de Saúde; Satisfação dos Consumidores.

Estudio transversal con objetivo de analizar el perfil de morbilidad y utilización de servicios de salud por ancianos en Programa de Salud Familiar Antônio Estevão de Carvalho, São Paulo, Brasil. Fueron utilizadas informaciones de 92 ancianos del datos del proyecto "Salud de la Familia - evaluación de la nueva estrategia de atención en el escenario de las políticas públicas". El análisis descriptivo señaló ancianos con edad media de 70,6 años; 64,1\% del sexo femenino; 93,5\% mencionaron al menos un problema de salud, especialmente hipertensión arterial (67,4\%) y diabetes mellitus (19,6 \%); 77,3\% buscaron atención de la salud; hospital gubernamental $(42,4 \%)$ fue el servicio más buscado. Las razones para escoja de los servicios fueron facilidad en acceso $(18,5 \%)$ y necesidad de atención $(7,6 \%)$. El principal motivo para satisfacción con los servicios fue la atención interpersonal, y para insatisfacción fue falta de medicamentos y larga espera en agentamiento de consultas. Descriptores: Salud del Anciano; Programa de Salud Familiar; Servicios de Salud; Satisfacción de los Consumidores.

\footnotetext{
${ }^{1}$ Universidade de São Paulo. São Paulo, SP, Brazil.

Corresponding author: Ruth Natalia Teresa Turrini

Escola de Enfermagem da Universidade de São Paulo Av. Dr. Enéas Carvalho Aguiar, 419 - CEP: 05.403-000. São Paulo, SP, Brazil.

E-mail: rturrini@usp.br
} 


\section{Introduction}

The aging of the population's age structure and consequently a bigger relative and absolute quantitative of the population who is 60 years old and older contributed to a notable demographic change in Brazil and in the world at the end of the twentieth century $^{(1)}$. In the 2010 census the elderly population reached 20.5 million people ${ }^{(2)}$ in Brazil, with almost 4.8 million in the state of São Paulo. Demographic changes modify the epidemiological profile of this population that begins to show a higher prevalence of chronic noncommunicable diseases (NCDs), which represents a problem for the health sector, which is not prepared to care appropriately for their chronic health problems ${ }^{(3)}$.

Studies have shown that the prevalence of NCDs in the elderly is high, especially hypertension, diabetes mellitus, cardiovascular and osteoarticular diseases $^{(1,4)}$. Due to the higher prevalence of NCDs and medications, the elderly tend to use more health services than other age groups. The health and social services contribute to an active aging of the population, the elderly look for health services, but the best adherence to health promotion and prevention measures come from specific actions, such as the influenza vaccine campaign ${ }^{(5)}$.

The economic resources of the elderly, especially from poor areas, are restricted to meeting their health needs. A study ${ }^{(6)}$ from 2003 that described the sociodemographic profile of the elderly from the Family Health Unit (FHU) Antonio Estevão (A.E.) de Carvalho identified that $14.3 \%$ earned up to one minimum wage and $65.7 \%$ two to three minimum wages in their family income; in $59.2 \%$ of the cases, one person contributed to this income and in $26.2 \%$, two people. Regarding the variables of housing, most seniors lived in houses (96.2\%), paid off (78.1\%), with an average number of rooms per household of 3.8 , most of them have indoor bathroom $(72,4 \%)$, public system for sewage facilities (98.1\%), public and domestic water supply (92.5\%), proper garbage collection (98.1\%), paving on the street $(97.2 \%)$ and lighting (95.3\%).

Aiming to understand better how older people solve their health problems, this study aimed to identify the profile of morbidity and use of health services of the elderly assisted in the Family Health Program from São Paulo, Brazil.

\section{Methods}

Descriptive epidemiological cross-sectional study that used as a source of information the database from the project "Family Health - Assessment of a new assistance strategy in the setting of public policies," funded by the Foundation for Research Support of the State of São Paulo (Public Policies Project - 00/019577). The original project had an inter-institutional character, and involved three institutions of higher education: Universidade de Santo Amaro, Faculdade Santa Marcelina and Universidade de São Paulo, as well as health professionals from the FHU Qualis A.E. Carvalho.

Data were collected through interviews with a structured form ${ }^{(7)}$ with the elderly in their homes or in the FHU. The 92 senior citizens included in the study were selected randomly through their registration forms from the FHU.

Founded in September 1998, the FHU studied is a benchmark in the region for other FHUs from the Project Qualis Santa Marcelina for presenting a specialized clinic. In the period from 2000 to 2004, the FHU A.E. Carvalho belonged to the health district of Vila Matilde and to the Administrative District of Artur Alvim, encompassing the neighborhood of A.E. Carvalho and Parque Paineiras, with about 100,000 residents. The FHU A.E. Carvalho had at the time of the study 3,774 registered families, totaling 14,082 users. The administrative district of Artur Alvim belongs to Penha sub-City Hall, a region that presents a Social Exclusion Index of -0.425 , an illiteracy rate of $3.76 \%$ and has half of household heads with completed elementary education ${ }^{(8)}$. 
The form used in the interviews from the original project was divided into four parts: (A) Socioeconomic Data; (B) Living Conditions; (C) Data about health and (D) a Form for the senior's caregiver. Most questions were structured and closed, but there were also some open questions to qualify the closed answers.

In the present study, to analyze morbidity and use of health services by the elderly registered at the FHU demographic variables (gender, education and age) were considered, reported health problems were coded according to the Tenth Revision of the International Classification of Diseases - ICD 10 $0^{(9)}$, the services used (type and maintaining source), the coverage area, the reason for choosing the service, the name of the service used and possible removal to the FHU, regular use of medications, medical appointments and satisfaction with the assistance at the FHU. To better understand the results, there was the need of telephone conversations with the FHU's manager.

For the analysis one used absolute and relative frequencies, measures of central tendency for continuous quantitative variables and association test by chi-square to verify the association between the study variables and gender and satisfaction at the FHU. This study was approved by the Ethics Committee from the Nursing College of the Universidade de São Paulo (Case No. 202/2001).

\section{Results}

The age of the elderly ranged from 60 to 89 years old (average 70.6 years old, standard deviation of 6.5 years and mode of 69 years). The age in the positions of the first quartile and the third quartile was 66.5 and 76.5 years old, respectively. Most of them were females (64.1\%), with no statistically significant difference between sex and age (Table 1). Regarding education, $80.2 \%$ of the elderly had not finished elementary school and $22 \%$ did not attend school, including the illiterate elderly and those who could read. It was observed that among males, there were some seniors who had finished high school or higher education (12.1\%).

Health problems were reported by $93.5 \%$ of the elderly and $52.3 \%$ of them reported from two to five NCDs. Among women there was a higher number of them with two to five health problems ( $p$ $=0.0181$ ).

The main problems reported were hypertension (67.4\%), diabetes mellitus (19.6\%). The proportion of seniors who had hypertension and diabetes was $15.2 \%$. Hypertension was more mentioned by women $(\mathrm{p}=0.0279)$.

Most seniors (88.0\%) made use of medications. No association was found between the use of medications and gender.

Table 1 - Distribution of the elderly by gender and demographic and morbidity variables

\begin{tabular}{|c|c|c|c|c|}
\hline \multirow[b]{2}{*}{ Variables } & \multicolumn{3}{|c|}{ Gender } & \multirow[b]{2}{*}{$\mathbf{p}$} \\
\hline & $\begin{array}{c}\text { Female } \\
\text { n (\%) }\end{array}$ & $\begin{array}{l}\text { Male } \\
\text { n (\%) }\end{array}$ & $\begin{array}{c}\text { Total } \\
\text { n (\%) }\end{array}$ & \\
\hline \multicolumn{5}{|l|}{ Age (years) } \\
\hline Until 69 & $30(50.8)$ & $19(57.6)$ & 49 (53.3) & \multirow{2}{*}{0.687} \\
\hline$>69$ & $29(49.2)$ & $14(42.4)$ & $43(46.7)$ & \\
\hline \multicolumn{5}{|l|}{ Education } \\
\hline Did not attend school & $13(22.4)$ & $7(21.2)$ & $20(22.0)$ & \\
\hline $\begin{array}{l}\text { Incomplete elementary } \\
\text { education }\end{array}$ & $37(63.8)$ & $16(48.5)$ & $53(58.2)$ & \\
\hline $\begin{array}{l}\text { Complete elementary } \\
\text { education }\end{array}$ & $8(13.8)$ & $6(18.2)$ & $14(15.4)$ & 0.086 \\
\hline $\begin{array}{l}\text { Complete High School or } \\
\text { higher education }\end{array}$ & - & $4(12.1)$ & $4(4.4)$ & \\
\hline \multicolumn{5}{|l|}{$\begin{array}{l}\text { Presence of health } \\
\text { problems }\end{array}$} \\
\hline Yes & $57(96.6)$ & $29(87.9)$ & $86(93.5)$ & $0.183^{\mathrm{F}}$ \\
\hline No & $2(3.4)$ & $4(12.1)$ & $6(6.5)$ & \\
\hline \multicolumn{5}{|l|}{$\begin{array}{l}\text { Number of health } \\
\text { problems }\end{array}$} \\
\hline One & $21(36.8)$ & $20(69.0)$ & $41(47.7)$ & \\
\hline Two & $18(31.6)$ & $5(17.2)$ & 23 (26.7) & 0.018 \\
\hline Three to five & $18(31.6)$ & $4(13.8)$ & $22(25.6)$ & \\
\hline
\end{tabular}


(continuation) the type of service, $12.0 \%$ used the FHU Qualis A.E.

Presence of Hypertension

\begin{tabular}{|c|c|c|c|c|}
\hline Yes & $45(76.3)$ & $17(51.5)$ & $62(67.4)$ & \multirow{2}{*}{0.028} \\
\hline No & $14(23.7)$ & $16(49.5)$ & $30(32.6)$ & \\
\hline \multicolumn{5}{|l|}{$\begin{array}{l}\text { Presence of Diabetes } \\
\text { Mellitus }\end{array}$} \\
\hline Yes & $12(20.3)$ & $6(18,2)$ & $18(19.6)$ & \multirow[b]{2}{*}{0.981} \\
\hline No & $47(79.7)$ & $27(81.8)$ & $74(80.4)$ & \\
\hline \multicolumn{5}{|l|}{ Medication use } \\
\hline Yes & $55(93.2)$ & $26(78.8)$ & $81(88.0)$ & \multirow[b]{2}{*}{0.051} \\
\hline No & $4(6.8)$ & $7(21.2)$ & $11(22.0)$ & \\
\hline \multicolumn{5}{|l|}{ When they see a doctor } \\
\hline On a regular basis & $31(58.5)$ & $18(56.3)$ & $49(57.6)$ & \\
\hline & & & & 0.981 \\
\hline Only when they need it & $22(41.5)$ & $14(43.7)$ & $36(42.4)$ & \\
\hline
\end{tabular}

F= Fisher's exact test

Figure 1 shows the distribution of all health problems reported by the elderly (160). It was observed that the diseases from Chapter IX - Diseases of the Circulatory System - were the most frequent (51.0\%), followed by Chapter IV - Endocrine, Nutritional and Metabolic Diseases - (18.1\%) and Chapter XIII - Diseases of the Musculoskeletal System and Connective Tissue (12.0\%). The remaining chapters contributed with $18.8 \%$ of referred complaints. In Chapter XIII, the back problems (9.8\%) were the most common.

When asked about how often they saw a doctor or went to a health service, $57.6 \%$ of respondents reported seeing a doctor on a regular basis and $42.4 \%$ only when they really needed it and there was no difference between genders ( $p=0.9808)$ (Table 2).

The main services sought according to the sustaining source were the philanthropic hospitals (43.6\%), private/health insurance (24.6\%). Although the sample was drawn from the register of the elderly, the demand for HBU/FHU was small (12.8\%), regardless of the gender $(\mathrm{p}=0.8379)$. Regarding

other hospitals and $18.3 \%$ health insurance services.

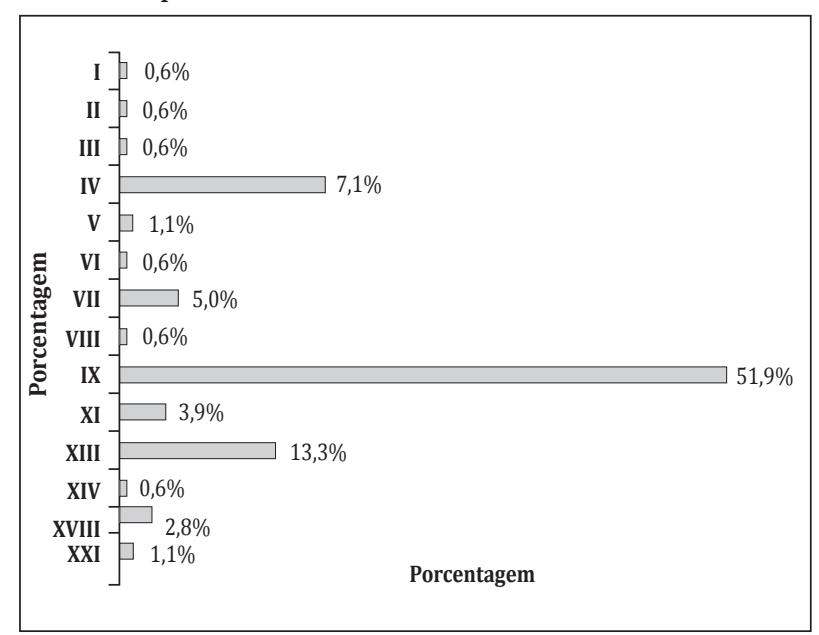

Figure 1 - Percentage distribution of morbidities according to the chapters of ICD-10

The reasons why older people chose the service were related to ease of access (32.7\%), the need for care $(28.8 \%)$, socio-economic conditions of the respondents $(15.4 \%)$, the service organization (15.24\%). The difference between genders was shown more present due to socioeconomic reasons in women and the need for care among men, although without statistical significance $(p=0.2581)$.

Table 2 - Distribution of the elderly according to the services use

\begin{tabular}{|c|c|c|c|c|}
\hline \multirow{3}{*}{ Variables } & \multicolumn{3}{|c|}{ Gender } & \multirow{3}{*}{$\mathbf{p}$} \\
\hline & Female & Male & Total & \\
\hline & n (\%) & n (\%) & n (\%) & \\
\hline
\end{tabular}

Type of service

Public Hospital

$8(17.4) \quad 3(13.0) \quad 11(15.9)$

Philanthropic Hospital

Private / Health Insurance HBU / FHU

21 (45.7) $9(39.2) \quad 30(43.6)$ $10(21.7) \quad 7(30.4) \quad 17(24.6) 0.838$

Service in the area of FHP

$\begin{array}{llll}\text { Yes } & 34(72.3) & 16(66.7) & 50(70.4) \\ & & & \\ \text { No } & 13(27.7) & 8(33.3) & 21(29.6)\end{array}$

Satisfaction with FHU

Qualis service 
(continuation)

\begin{tabular}{lcccc} 
Yes & $44(74.6)$ & $25(78.1)$ & $69(75.8)$ & 0.904 \\
No & $15(25.4)$ & $7(21.9)$ & $22(24.2)$ & \\
$\begin{array}{l}\text { Reason for choosing the } \\
\text { service }\end{array}$ & & & \\
$\begin{array}{l}\text { Accessibility } \\
\begin{array}{l}\text { Socioeconomic } \\
\text { conditions }\end{array}\end{array}$ & $10(30.3)$ & $7(36.8)$ & $17(32.7)$ \\
$\begin{array}{l}\text { Health Insurance } \\
\text { Need for care }\end{array}$ & $3(21.2)$ & $1(5.3)$ & $8(15.4)$ & \\
Organization & $7(21.2)$ & $8(42.1)$ & $15(28.8)$ & 0.258 \\
& $6(18.2)$ & $2(10.5)$ & $8(15.4)$ \\
\hline
\end{tabular}

Due to health problems, the majority (77.3\%) reported they looked for specific health care. The proportion of respondents who reported not looking for medical care, for thinking it was not necessary or for not knowing who to look for or where to go was $20.4 \%$.

When one studied the relationship between demand for service and age, education, medication use and presence of pathological conditions there was no significant association to explain the variations in the use of health services, being it on a regular basis or due to health problems among the elderly. Considering the elderly with hypertension, it was found that $54.8 \%$ of them visited the doctor regularly, while this proportion among diabetic patients was $66.7 \%$.

Through telephone conversations with the manager of the FHU Qualis, one obtained information about referral services in 2003 for patients routing. For conducting the examinations (x-ray, ultrasound, laboratory exams, endoscopy, cardiac catheterization and electrocardiography) and attendanceby specialists (urologist, ophthalmologist and cardiologist) the reference services were a Basic Health Unit (BHU) next to A. E. Carvalho and four hospitals in the eastern region of São Paulo and three in the southern region. Admissions of patients were conducted through the references of the Mobile Emergency Care Service (MECS, or SAMU in Portuguese) or Rescue (Regaste in Portuguese - a state project of pre-hospital care developed by the Fire Department), or the patients were sent to the emergency rooms of two other hospitals located in the eastern region. Individuals who needed general surgery were sent to a university hospital in the south of São Paulo.

When seeking care in the services mentioned to $34.8 \%$ of the elderly were sent as counter-reference to the FHU Qualis A. E. Carvalho, and 50.3\% had looked for Qualis to set appointment more than twice, with a minimum of two and a maximum of ten times.

The elderly were satisfied concerning the care received at the FHU Qualis, so that $21.7 \%$ said that the service is excellent, $53.3 \%$ good, $19.6 \%$ fair. No statistically significant difference between satisfaction and demographic variables (gender, education, age) was observed. The same occurred when one verified the association of satisfaction with variables of morbidity and service use (Table 3).

Table 3 - Distribution of the elderly according to the satisfaction and variables of morbidity and use of health services

\begin{tabular}{|c|c|c|c|c|}
\hline \multirow{3}{*}{ Variables } & \multicolumn{3}{|c|}{ Satisfaction with care } & \multirow{3}{*}{$\mathbf{p}$} \\
\hline & Yes & No & Total & \\
\hline & n (\%) & n (\%) & n (\%) & \\
\hline \multicolumn{5}{|l|}{$\begin{array}{l}\text { Number of health pro- } \\
\text { blems }\end{array}$} \\
\hline One & $30(75.0)$ & $10(25.0)$ & $40(100.0)$ & \multirow{3}{*}{0.731} \\
\hline Two & $18(78.3)$ & $5(21.7)$ & $23(100.0)$ & \\
\hline Three to five & $15(68.2)$ & 7 (31.8) & $22(100.0)$ & \\
\hline \multicolumn{5}{|l|}{ Presence of Hypertension } \\
\hline Yes & $44(72.1)$ & 17 (27.9) & $61(100.0)$ & \multirow{2}{*}{0.361} \\
\hline No & $25(83.3)$ & $5(26.7)$ & $30(100.0)$ & \\
\hline \multicolumn{5}{|l|}{$\begin{array}{l}\text { Presence of Diabetes } \\
\text { Mellitus }\end{array}$} \\
\hline Yes & $16(88.9)$ & $2(11.1)$ & $18(100.0)$ & \multirow{2}{*}{0.221} \\
\hline No & $53(72.6)$ & $20(27.4)$ & $73(100.0)$ & \\
\hline \multicolumn{5}{|l|}{ Medication use } \\
\hline Yes & $60(75.0)$ & $20(25.0)$ & $80(100.0)$ & \multirow{2}{*}{$1.000^{\mathrm{F}}$} \\
\hline No & $9(81.8)$ & $2(18.2)$ & $11(100.0)$ & \\
\hline \multicolumn{5}{|l|}{ When they see a doctor } \\
\hline On a regular basis & $39(79.6)$ & $10(20.4)$ & $49(100.0)$ & \multirow[b]{2}{*}{0.371} \\
\hline Only when they need it & $24(68.6)$ & $11(31.4)$ & $35(100.0)$ & \\
\hline
\end{tabular}

Type of service 
(continuation) bigger longevity of women compared to men ${ }^{(10,12,14)}$.

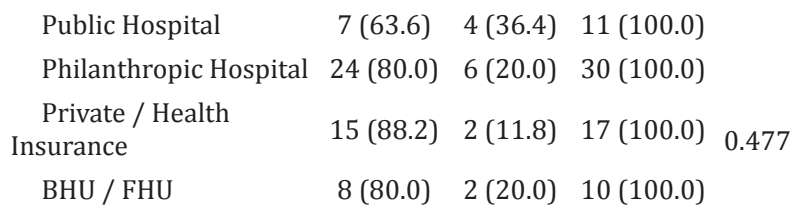

Service in the area of FHP

\begin{tabular}{lcccc} 
Yes & $38(77.6)$ & $11(22.4)$ & $49(100.0)$ & \\
$\quad$ No & $17(81.0)$ & $4(19.0)$ & $21(100.0)$ & \\
$\begin{array}{l}\text { Reason for choosing the } \\
\text { service }\end{array}$ & & & & \\
$\quad$ Accessibility & $12(75.0)$ & $4(25.0)$ & $16(100.0)$ & \\
$\begin{array}{l}\text { Socioeconomic con- } \\
\text { ditions }\end{array}$ & $6(75.0)$ & $2(25.0)$ & $8(100.0)$ & \\
$\quad \begin{array}{l}\text { Health Insurance } \\
\text { Need for care }\end{array}$ & $4(100.0)$ & - & $4(100.0)$ & 0.747 \\
$\quad 13(86.7)$ & $2(13.3)$ & $15(100.0)$ & \\
Organization & $6(75.0)$ & $2(25.0)$ & $8(100.0)$ & \\
\hline F = Fisher's exact test & & & &
\end{tabular}

The main reason for satisfaction was the interpersonal care and for dissatisfaction, lack of medicines and long wait to set appointments.

\section{Discussion}

The proportion of the elderly with ages of 80 years old or older was lower than the ones found in studies of Alto Vale do Itajaí-SC $(10.85 \%)^{(5)}$, CampinasSP $(14.7 \%)^{(10)}$, Botucatu-SP $(15 \%)^{(11)}$, Caracol-PI $(9.8 \%)^{(12)}$, Garrafão do Norte-PA $(18.6 \%)^{(12)}$, UberabaMG $(13.5 \%)^{(13)}$, Teixeira-MG $(15.6 \%)^{(14)}$, Fortaleza-CE $(25 \%)^{(15)}$; but similar to units from the south region as Nova Roma-RS $(8.8 \%)^{(16)}$.

The proportion of the elderly with no education in this study was lower than those observed in other places that presented frequencies of 41.0 and $63.0 \%$ among old patients attended in health services of the FHP from the south and northeast regions, respectively ${ }^{(2)}$. The proportion of the elderly with elementary education in this study is similar to those reported by other studies ${ }^{(11,16-17)}$, and it is higher than studies in Alto Vale do Itajaí-SC $(9.18 \%)^{(5)}$, Caracol-PI $(10.6 \%)$ and Garrafão do Norde-PA (13.6\%) ${ }^{(12)}$.

The predominance of females reflected a
One should also consider the fact that more women attend the BHU/FHU and the source for selection of research subjects was the FHU. Other epidemiological studies $^{(5,10-11,13-15,16)}$ showed similar results to those found in this investigation. The tendency of women live more than men, showing a lower mortality, occurs worldwide, but that does not mean they enjoy better health conditions ${ }^{(2)}$. It can be observed in the present study that more than half of the women had two or more health problems, while men had predominantly only one.

The number of seniors who reported presence of any chronic diseases revealed a high demand for permanent care of health services. However, this finding could be attributed to the fact that respondents were selected from among those registered at the FHU.

In a study conducted with an old population who lived in São Carlos-SP, one observed a prevalence of obesity in older women associated with the presence of diabetes mellitus when compared to the male population ${ }^{(4)}$. In Fortaleza, about $80.0 \%$ had morbidities, predominating circulatory diseases, followed by musculoskeletal and connective tissue diseases $^{(15)}$. The most common morbidities were hypertension (61.0\%), back problems $(60.0 \%)$, poor circulation and diabetes mellitus (approximately $20.0 \%$ each). Similar findings to other studies ${ }^{(11-14)}$.

A study to analyze inequalities in mortality from chronic diseases among the elderly conducted in the states of Brazil pointed out that cardiovascular diseases in the elderly are the most prevalent causes among the diseases analyzed. And they follow the trend of the population's aging, being higher at the states with more advanced stages of aging and better socioeconomic indicators (South and Southeast) ${ }^{(3)}$, an index that shows the importance of controlling hypertension in the region of this study. In another study hypertension accounted for $68.6 \%$ and diabetes mellitus for $18.3 \%$ of the elderly population attended at the BHU in Fortaleza-CE ${ }^{(17)}$; in the populations over 60 years old in Botucatu-SP(11) hypertension occurred 
in $44.2 \%$ of the population and in Alto Vale Itajaí-SC ${ }^{(5)}$ $86.20 \%$ had cardiovascular diseases.

Generally similar to this study, hypertension, diabetes mellitus and osteoarticular disorders appear as the most frequent in the old population. Public health policies have not incorporated musculoskeletal disorders in their actions of prevention and control. However, as observed in the $\mathrm{SABE}^{(1)}$ project, $83.2 \%$ of individuals with rheumatism/arthrosis/arthritis had pain and $63.1 \%$ had limitation due to the disease. This situation contributes to the reduction of physical activities among older people, harming the measures to control hypertension and diabetes related to changes in lifestyle habits.

The prevalence of medication use among the elderly in this study was high, especially among women. In a research conducted with elderly people in the southern region, $91.0 \%$ reported the use of medication $^{(5)}, 78.16 \%$ of the elderly from Alto Vale Itajaí-SC said it is part of their routine, out of these $44.83 \%$ self-medicated without supervision and said they made no mistakes. In Fortaleza $66.7 \%$ of the elderly used medications regularly ${ }^{(15)}$. In southern Santa Catarina one observed the use of 3.5 drugs per individual, with the number of daily doses of 5.4 considered polypharmacy ${ }^{(18)}$.

In general, most elderly people sought health services or the doctor, through routine visits, but many of them did that only when they needed it, that is, in acute situations or in serious morbidities, increasing the possibility of sequels and negative effects on the functional capacity of the elderly. The variables: education, age, medication use and presence of morbidity were not statistically significant on the use of health services by the elderly.

In a multicenter study conducted in Campinas, Botucatu, São Paulo municipalities (Itapecerica da Serra, Embu and Taboão da Serra) and the district of Butantan (São Paulo) $75.2 \%$ of the elderly reported visiting the health center regularly, without significant difference between values of lower or higher per capita income $^{(10)}$. In another SABE investigation, $69.0 \%$ of seniors used healthcare facilities and not using it was related to low disease severity, quality and distance of services and costs ${ }^{(19)}$. In Santa Catarina $65.4 \%$ of seniors reported having sought health services two or more times in the last year ${ }^{(18)}$.

In the present study with data collected in 2003 were not investigated the use of health services by the elderly, but the percentage of those who visited the doctor regularly or only when they needed it reached $90.0 \%$. It is worth remembering that at that time the FHU studied was taken as a model.

Regarding the type of service used, another study with the elderly from São Paulo revealed that about half of the attendances with old people occurred in public services ${ }^{(19)}$, being the hospital the most present institution ${ }^{(19)}$. Regarding the use of private services, the frequency of use was higher $(48.3 \%)^{(15)}$ than in the present study, which was expected because in this study the elderly population lives in a poor region of São Paulo with high poverty levels.

The study data are consistent with the records of the PNAD (National Household Survey) 2008 ${ }^{(20)}$ from São Paulo, which showed that only $3.4 \%$ of the elderly aged over 65 had a health insurance. Data obtained in 2010 in Guarapuava, Parana, identified that $12.1 \%$ of the elderly registered in the basic health unit studied had a private health insurance ${ }^{(21)}$.

Referral services obtained in 2003 were modified under the current management of the Health Department. For admissions, hospitals from that period remain as references. Moreover, these services are indicated for specialized care. Other procedures are set through a regulated and computerized schedule for the city of São Paulo. This new system seeks to supply the demand of the population from the regions of São Paulo, but for the elderly public it can create difficulties in access due to the bigger distance of the services from their homes, since they are located in other regions of São Paulo.

Regarding the percentage of the elderly sent from the services chosen by them to the FHU Qualis (counter-reference) it can be inferred that these 
subjects had problems or complaints that could be resolved in FHU Qualis' primary care.

Regarding satisfaction with the care offered at FHU Qualis, most seniors were pleased characterizing the service as "good". A similar finding was observed in a study with the elderly in the region of Qassim in Saudi Arabia, where $76.9 \%$ of seniors were satisfied with the care received ${ }^{(22)}$. Although a restructuring of the service is desired for the elderly's care, in a systematic review $19.7 \%$ of the references found observed inequality in the use and access to health services and inadequate care model ${ }^{(23)}$.

Although the data collection of this study was conducted ten years ago, it is observed that the time for scheduling appointments is still an obstacle for meeting the health needs of the population. Study with elderly individuals who practice physical activities showed that $48.4 \%$ attributed the wait to set appointments as one of the difficulties in the use of health services ${ }^{(24)}$.

As a limitation of this study there is the fact that the information are about senior citizens registered in the FHU from the region A. E. Carvalho, and even being a random sample, its results do not allow generalizations to the elderly population of São Paulo, Brazil.

\section{Conclusion}

The study achieved the objective of knowing how the elderly registered at the FHU Qualis A. E. Carvalho use health services. The elderly population was characterized as young as it was in the age group between 60 and 70 years old and predominantly females. Most seniors had at least one health problem (93.5\%), the most mentioned disease was hypertension (67.4\%) and $88.0 \%$ of the elderly use medications. Despite the large quantity of seniors who used medications, one observed that $57.6 \%$ visited the doctor regularly. The elderly who participated in the study were registered at the FHU, however, only $12.8 \%$ of them looked for care in this unit when it was necessary. On the other hand, $50.3 \%$ of the patients who were sent to the FHU QUALIS needed to go to the unit twice or more to set an appointment.

It was observed that the elderly often look for assistance to solve their health problems and most of them used services from their area. Although the service has a system to send patients for examinations and specialized care, these are far from the elderly's homes, which is a problem given the advanced age of the patients, health problems and low income of the population of this region.

In general, older people were satisfied with the health services offered, valuing interpersonal relationships. Reasons for dissatisfaction are often observed in public services of health care. The results of the services use show difficulties similar to those found at the BHU, such as the lack of medicines and the difficulty in access.

The study contributes to measure the elderly's accessibility to health services and to show that both in the past and currently, the wait to set an appointment and the lack of medicines in primary health care units are still a problem to be overcome by public health policies. The Unified Health System and the reference and counter-reference system still have as a challenge to meet their demands and offer services with hierarchical levels of easy access to the population.

\section{Acknowledgements}

The research project "Family Health Assessment of a new assistance strategy in the setting of public policies," funded by the Foundation for Research Support of the State of São Paulo (Public Policies Project - 00/01957-7).

\section{Collaborations}

Cabrelli R contributed to the conception of the study, data collection, analysis, interpretation of data and writing of the article. Sousa CS contributed to the 
analysis, data interpretation and writing of the article. Turrini RNT contributed to data interpretation, drafting of the article and final approval of the version to be published. Cianciarullo TI contributed to the drafting of the article and final approval of the version to be published.

\section{References}

1. Gomes MMF, Turra CM, Figoli MGB, Duarte YAO, Lebrão ML. Associação entre mortalidade e estado marital: uma análise para idosos residentes no Município de São Paulo, Brasil, Estudo SABE, 2000 e 2006. Cad Saúde Pública. 2013; 29(3):566-78.

2. Instituto Brasileiro de Geografia e Estatística (IBGE). Censo Demográfico 2010 - Características gerais da população, religião e pessoas com deficiência. Rio de Janeiro: IBGE; 2011.

3. Alves DB, Barbosa MTS. Desigualdades na mortalidade por doenças crônicas entre idosos e sua associação com indicadores socioeconômicos no Brasil. Rev Bras Ciênc Env Hum. 2010; 7(1):22-33.

4. Aurichio TR, Rebelatto JR, Castro AP. Obesity among older people of the city of São Carlos, SP, Brazil, and its association with diabetes mellitus and joint pain. Fisoter Pesqui. 2010; 17(2):114-7.

5. Farias RG, Santos SMA. Determinants influence of aging among elderly more elderly. Texto Contexto Enferm. 2012; 21(1):167-76.

6. Murai OC, Turrini RNT, Chaccur MIB, Bersusa A, Marra CC, Duarte YAO et al. Estudo comparativo do perfil sócio-demográfico e de utilização dos serviços de saúde da população idosa residente em duas áreas do município de São Paulo. In: Cianciarullo TI, Silva GTR, Cunha ICKO, organizadores. Uma nova estratégia em foco: o programa de saúde da família: identificando as suas características no cenário do SUS. São Paulo (SP): Ícone; 2005. p. 221-47.

7. Turrini RNT, Marra CC, Murai HC, Chaccur MIB, Duarte YAO, Bersusa A et al. Avaliando a assistência ao idoso: a construção de um formulário para coleta de dados. In: Cianciarullo TI, Gualda DMR, Silva GTR, Cunha ICKO, organizadores. Saúde na família e na comunidade. São Paulo: Robe; 2002. p. 340-74.

8. Cunha K, Souza LA, Ohara R. 0 cenário de geração e viabilização do Projeto Saúde da Família: a construção da história da Unidade de Saúde da Família do A.E. Carvalho. In: Cianciarullo TI, Silva GTR, Cunha ICKO, organizadores. Uma nova estratégia em foco: o programa de saúde da família: identificando as suas características no cenário do SUS. São Paulo: Ícone; 2005. p. 55-92.

9. Ministério da Saúde (BR). Classificação Estatística Internacional de Doenças e Problemas Relacionados à Saúde (CID-10). Brasília: Ministério da Saúde; 2008.

10. Francisco PMSB, Belon AP, Barros MBA, Carandina L, Alves MCGP, Goldabaum M, et al. Self-reported diabetes in the elderly: prevalence, associated factors, and control practices. Cad Saúde Pública. 2010; 26(1):175-84.

11. Campos FG, Barrozo LV, Ruiz T, César CLG, Barros MBA, Carandina L, et al. Spatial distribution of elderly individuals in a medium-sized city in São Paulo state, Brazil, according to key sociodemographic and morbidity characteristics. Cad Saúde Pública. 2009; 25(1):77-86.

12. Cesar JA, Oliveira-Filho JA, Bess G, Cegielka R, Machado J, Gonçalves TS, et al. Profile of elderly population in two poor municipalities in North and Northeast Brazil: the results of a cross-sectional population-based survey. Cad Saúde Pública. 2008; 24(8):1835-45.

13. Ferreira PCS, Tavares DMS, Rodrigues RAP. Sociodemographic characteristics, functional status and morbidity among older adults with and without cognitive decline. Acta Paul Enferm. 2011; 24(1):29-35.

14. Pereira RJ, Cotta RMM, Franceschini SCC, Ribeiro RCL, Tinoco ALA, Rosado LEFPL, et al. Analysis of the social and health profile of the elderly: the relevance of the Family Health Program. Rev Med Minas Gerais. 2010; 20(1):5-15.

15. Clares JWB, Freitas MC, Almeida PCA, Galiza FT, Queiroz TA. Actions of the community health agent in the diagnosis of pulmonary tuberculosis. Rev Rene. 2011; 12(n. esp.):988-94.

16. Rigo II, Paskulin LMG, Morais EP. Functional ca- 
pacity of older persons from a rural community of Rio Grande do Sul. Rev Gaúcha Enferm. 2010; 31(2):254-61.

17. Victor JF, Ximenes LB, Almeida PC, Vasconcelos FF. Sociodemographic and clinical profile of elders who receive care in a Family health unit. Acta Paul Enferm. 2009; 22(1):49-54.

18. Galato D, Silva ES, Tiburcio LS. Study of the use of medicine in elderly living in a city in the South of Santa Catarina (Brazil): a look at the polymedication. Ciênc Saúde Coletiva. 2010; 15(6):2899-905.

19. Louvison MCP, Lebrão ML, Duarte YA, Santos JLF, Malik AM, Almeida ES. Inequalities in access to health care services and utilization for the elderly in São Paulo, Brazil. Rev Saúde Pública. 2008; 42(4):733-40.
20. Instituto Brasileiro de Geografia e Estatística (IBGE). Pesquisa Nacional por Amostra de Domicílios (PNAD 2008). Rio de Janeiro: IBGE; 2008.

21. Pilger $C$, Menon MU, Mathias TAF. Health services use among elderly people living in the community. Rev Esc Enferm USP. 2013; 47(1):213-20.

22. Salem SA. Patient satisfaction with primary health care services in Qassim province, Saudi Arabia. Egyp J Comm Med. 2010; 28(3):89-108.

23. Camacho ACLF, Coelho MJ. Public policies for the elderly's health: systematic review. Rev Bras Enferm. 2010; 63(2):279-84.

24. Virtuoso JF, Mazo GZ, Menezes EC, Cardoso AS, Dias RG, Balbé GP. Perfil de morbidade referida e padrão de acesso a serviços de saúde por idosos praticantes de atividade física. Ciênc Saúde Coletiva. $2012 ; 17(1): 23-31$. 